\title{
Vermicomposted tannery wastes in the organic cultivation of sweet pepper: growth, nutritive value and production
}

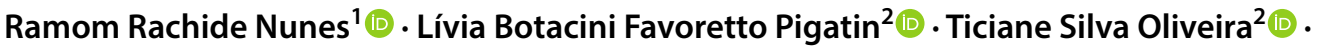 \\ Rhaissa Mecca Bontempi ${ }^{2}$ (1) $\cdot$ Maria Olímpia Oliveira Rezende ${ }^{2}$ (D)
}

Received: 11 October 2017 / Accepted: 1 September 2018 / Published online: 8 September 2018

(c) The Author(s) 2018

\begin{abstract}
Purpose In this study, vermicomposted tannery wastes were applied in the organic cultivation of sweet pepper in a greenhouse. The effects of this organic matter addition on plant development and on the distributions of $\mathrm{Cr}(\mathrm{III})$ and $\mathrm{Cr}(\mathrm{VI})$ in plant tissues and organs were assessed.

Methods In a greenhouse, organic sweet peppers were cultivated adding vermicomposted tannery to the substrate (sample VRC) and the results were compared with the samples control (dYL; only soil) and reference (NPK; adding mineral fertilizer). The growth, nutritive value and fruit production were assessed to evaluate the plant development in different types of substrate. Besides evaluating the biostimulant effect of vermicomposts, the distributions of $\mathrm{Cr}$ in plant tissues were also studied. Results Up to three harvested sweet peppers were obtained per plant, compared with only one fruit for the reference treatment with NPK addition. Based on the Cr dynamics in the plants, the highest concentration was found in the fruits, varied as follows: fruits $>$ stem and stalks $>$ leaves $=$ root; however, the $\mathrm{Cr}$ concentration in the fruits was statistically the same across all treatments. Additionally, only $\mathrm{Cr}(\mathrm{III})$ was detected and quantified in the fruits.

Conclusion The addition of vermicompost was biostimulating to plants and positively influenced their development. Based on the $\mathrm{Cr}$ dynamics in the plants, since the $\mathrm{Cr}$ concentration was the same across all treatments, it demonstrated that the addition of tannery residues to the vermicompost did not negatively influence the health benefits or food security of the produced fruits.
\end{abstract}

Keywords Waste management $\cdot$ Tannery wastes $\cdot$ Vermicomposting $\cdot$ Sweet peppers

\section{Introduction}

In Brazil, annually an amount of $\sim 44.7$ thousand metric tons of leather is manufactured. To hold this high production, approximately 450 tanneries plants, located all over the country, make Brazil the fourth leading producer in the

Electronic supplementary material The online version of this article (https://doi.org/10.1007/s40093-018-0217-7) contains supplementary material, which is available to authorized users.

Ramom Rachide Nunes

ramom.rachide@ufrpe.br

1 Academic Unit of Serra Talhada, Federal Rural University of Pernambuco, Serra Talhada, PE, Brazil

2 São Carlos Institute of Chemistry, University of São Paulo, São Carlos, Brazil world, behind China (209.8), India (52.7), and Italy (51.7 thousand metric tons) (CETESB 2005).

Environmental toxins and demand for safe disposal of industrial wastes are currently the topics of concern. The leather industry is associated with the generation of huge amounts of solid wastes, and waste disposal is a serious problem. Untreated solid waste and wastewater generated by the tanning industry can cause serious environmental damage, particularly to surface water and groundwater (Belay 2010; Vig et al. 2011; Dixit et al. 2015; Scaglia et al. 2016).

Usually, $\mathrm{Cr}$ is introduced mainly in the form of $\mathrm{Cr}_{2}\left(\mathrm{SO}_{4}\right)_{3}$ [chromium (III) sulfate] aiming to stabilize the leather by cross linking the collagen fibbers. As final product, the tanned skin by adding $\mathrm{Cr}$ salts shows a better texture and quality, resulting in manufactured products with a higher market value. Besides $\mathrm{Cr}$, other contaminants are added in the tanning process, e.g., sodium and ammonium sulfate, thiobenzothiazole, kerosene, etc., but in small 
concentration. To avoid such pollution, specific chemical, physical and biological treatments have been adopted to reduce waste toxicity and enhance tannery waste use/recycling systems (Aira et al. 2008; Yang et al. 2014; Scaglia et al. 2016; Makkar et al. 2017).

In this context, vermicomposting is an effective technology that can reduce the toxic effects of tannery wastes, based on earthworm activity of Eisenia fetida L., which also improves nutrient availability of OM. Earthworms transform organic residues both physically and chemically by mixing and grinding the waste mass, whereas microbes in the guts of worms are responsible for the biochemical transformation of OM (Aira et al. 2008; Yang et al. 2014; Scaglia et al. 2016; Makkar et al. 2017). Moreover, earthworms can accumulate heavy metals in their chloragogen cells, resulting in detoxification of polluted biomass (Huges 1980; Ricci 1996; Nunes et al. 2016; Karimi et al. 2017).

Several forms of industrial waste (i.e., paper mill sludge, sugar industry waste and textile waste) have been successfully vermicomposted to obtain useful and safe organic inputs (Ravindran et al. 2008; Vig et al. 2011). In addition, vermicompost applications increase the yield and growth of several crops, mainly because these organic inputs are rich in plant-available nutrients, such as phosphates, nitrates, and exchangeable soluble potassium and calcium (Arancon et al. 2006; Bachman and Metzger 2008; Gopinath et al. 2009). The use of organic amendments for improving soil productivity and health has been reported previously, usually to provide a source of nutrients in organically managed systems, particularly in organic agriculture practices (Ramesh et al. 2006; Gopinath et al. 2009; Singh et al. 2011; Karimi et al. 2017).

Sweet pepper (Capsicum annuum L.) is a highly consumed vegetable that is better adjusted to and, therefore, most frequently produced under greenhouse conditions (Pereira 1990; Scivittaro et al. 1999; Silva et al. 2002; Herman et al. 2008). Greenhouse cultivation of sweet pepper demands the intensive use of agri-inputs and labor; moreover, this intense activity is part of a dynamic market in which seasonal prices fluctuate, demanding rigorous planning by the producer for both crop production and the use of technology to decrease production risks and increase profits (Pereira 1990; Silva et al. 2001; Abul-Soud et al. 2014).

Vermicompost fertilization is well known for its effects on plant nourishment, which result in reduced requirements for (or the elimination of) chemical pesticides and inorganic fertilizers. Additionally, an understanding of the effects of OM addition on sweet pepper plants at each stage of development can provide information to assist with fertilizing programs for crops, even in greenhouses (Bachman and Metzger 2008; Llaven et al. 2008; Gopinath et al. 2009; Abul-Soud et al. 2014).
Therefore, the aim of this work was to determine the effects of application of vermicomposted tannery wastes on organic sweet pepper cultivation in the greenhouse. In particular, the effects of this organic matter addition on plant development, i.e., growth, nutritive value and fruit production, were assessed. Additionally, the distribution of chromium, a heavy metal in tannery wastes, was determined in pepper plant tissues and organs.

\section{Materials and methods}

\section{Vermicompost production}

This study was conducted using vermicomposted tannery wastes in the form of both sludge and tanned chips mixed with cattle manure and sawdust. The vermicomposters were established in $25 \mathrm{~L}$ plastic barrels containing different proportions of fresh wastes (based on dry volume). The proportion of the residues was determined by a combination of their C:N ratios. Designed in triplicate, each barrel received $20 \mathrm{~L}$ of the mixture of wastes as follows, based on fresh volume: (1) sludge mix (VRC-S): $14.5 \mathrm{~L}$ of cattle manure, $2.5 \mathrm{~L}$ of sawdust, and $3 \mathrm{~L}$ of sludge; (2) tanned chips mix (VRC-C): $14 \mathrm{~L}$ of cattle manure, $2 \mathrm{~L}$ of sawdust, and $4 \mathrm{~L}$ of tanned chips; and (3) sludge + tanned chips mix (VRC$\mathrm{SC}$ ): $14 \mathrm{~L}$ of cattle manure, $2 \mathrm{~L}$ of sawdust, $1.5 \mathrm{~L}$ of sludge, and $2.5 \mathrm{~L}$ of tanned chips. For comparison, a vermicomposter with no leather wastes was also prepared (standard treatment, VRC-STD) by mixing fresh-volume $17 \mathrm{~L}$ of cattle manure and $3 \mathrm{~L}$ of sawdust.

Previously analyzed, the raw materials presented as main characteristics: (1) sludge (S): $\mathrm{pH} 7.83$, OM 36.32\%, TOC $17.20 \%$, N 4.63\%; (2) tanned chips (C): pH 3.31, OM $84.96 \%$, TOC $48.26 \%$, N $13.30 \%$; (3) cattle manure: $\mathrm{pH}$ 8.88 , OM $63.02 \%$, TOC $34.30 \%, \mathrm{~N} 2.02 \%$; and (4) sawdust pH 4.84 , OM $89.11 \%$, TOC $52.69 \%$, N $0.43 \%$.

After the mixtures were prepared, the material stabilized for 1 week; then, all of the contents were turned manually once per week. For vermicompost production, 500 newly born earthworms (Eisenia fetida L.) were added to each vermicomposter. The experiment was conducted during the months of April-August 2014 (135 days) in the Laboratory of Environmental Chemistry (LQA), Institute of Chemistry of São Carlos (IQSC), University of São Paulo (USP), Brazil (Nunes et al. 2016).

To characterize the vermicomposts, $0.5 \mathrm{~L}$ samples were collected from each vermicomposter. Then, a single combined sample was prepared from the triplicate samples. The material was air-dried, ground and sieved to $0.5 \mathrm{~mm}$. In triplicate, the OM (NEN 5754 1994), total organic carbon (TOC) (ISO 10694 1995), pH (ISO 10390 1994), cation exchange capacity (CEC) (ISO 11260 1994), humic 
acid content (HA) (Swift 1996), macro and micronutrients (EMBRAPA 2017), and C:N ratio (using a Perkin Elmer 2400; North Billerica, MA, USA) were determined in the vermicomposts.

\section{Sweet pepper organic cultivation}

Samples of a dystrophic yellow latosol (dYL) were collected on Campus II of the University of São Paulo (21 ${ }^{\circ} 59^{\prime} 51^{\prime \prime}$, $47^{\circ} 56^{\prime} 20^{\prime \prime} \mathrm{W}$ ). Using a tractor, 1.0 ton of soil was drilled at a $40.0 \mathrm{~cm}$ depth in the arable fraction. Thereafter, the material was sieved to $2.0 \mathrm{~mm}$ and air-dried. Soil collection and preparation were conducted in February 2014, which had an average temperature of $24^{\circ} \mathrm{C}$ and precipitation of $198 \mathrm{~mm}$.

To characterize the $\mathrm{dYL}$ soil, the following attributes were determined: $\mathrm{pH}$, organic matter $(\mathrm{OM})$, total organic carbon (TOC), cation exchange capacity (CEC), base saturation (BS), macro- and micronutrients, particle-size distribution, and soil texture.

Sweet pepper seedlings (biologically certified) were purchased from SouAgro- Sociedade Agropecuária (São Carlos, SP, Brazil). Each seedling was $\sim 3.0 \mathrm{~cm}$ in height and $\sim 30$ days from planting. Seedlings were grown on a commercial substrate of coconut fibre and pine bark (Bioplant ${ }^{\circledR}$, Nova Ponte, MG, Brazil) and were watered manually daily.

When seedlings reached $5.0 \mathrm{~cm}$ in height and had at least five permanent leaves, in addition to a healthy appearance, the seedlings were transplanted into $0.5 \mathrm{~L}$ plastic pots using the same commercial substrate. At $10 \mathrm{~cm}$ in height, the plants were transplanted to $25.0 \mathrm{~L}$ vessels for the beginning of the experiment.

Each seedling was grown in a $25.0 \mathrm{~L}$ vessel containing $20.0 \mathrm{~L}$ of substrate. The cultivation was monitored daily, and to prevent pests, an aqueous extract of orange peel was sprayed on the leaves, a natural repellent that insects avoid. The invasive plants were eliminated manually. Using a watering can (manual watering), $1.0 \mathrm{~L}$ of water was added daily to each plant. The volume of $1.0 \mathrm{~L}$ was determined from the wilting point, obtained by preliminary tests.

For the organization of the experiment, the vessels were distributed randomly on benches, with 42 vessels distributed on two benches, constructed from two boards on three tripods, with a size of $6.0 \times 0.6 \mathrm{~m}$. In total, 24 vessels were arranged in a $2 \times 12$ system (column $\times$ row) and the other 14 vessels in a $2 \times 7$ system (column $\times$ row). Each column corresponded to one board. The distance between the vessels was $10.0 \mathrm{~cm}$ and positions were changed weekly at random. Positions were modified to minimize possible external influences, e.g., shade and wind.

Agronomic assays were carried out in triplicate. According to the different types of substrates, the following treatments were studied: SP-dYL: Soil without previous management (control treatment); SP-NPK: Soil and 3.0\%
(V/V) of mineral NPK fertilizer at 12:5:14 (reference treatment); and SP-VRC: Soil and vermicomposts at concentrations of 1.5, 3.0 and $6.0 \%(\mathrm{~V} / \mathrm{V})($ Table 1).

\section{Monitoring of sweet pepper cultivation}

Sweet pepper growth was monitored biweekly using a metric scale. The height (stalk size) of the plants was measured from the base (substrate) to the culm apex (highest point of the stem). The number of fixed leaves (below the apex) was counted and recorded every 2 weeks for each plant. In the first month, the count was weekly.

The width $(w)$ and length $(h)$ of the five largest leaves of each plant were measured every 15 days. From these data, the average leaf area $(A)$ was estimated (Eq. 1) (Lorenzeni et al. 2015).

$A=(0.6379 \times w \times h)^{0.9816}$

Four periods related to flowering and the formation of green and mature fruits were assessed with daily monitoring. The average flowering time was based on initiation of flowering. Fruit formation was measured from shortly after petal fall. Formation of stable green fruits was determined by size and appearance (intense green). The average maturation time was determined by formation of stable, full-red (mature) fruits.

Table 1 Details of samples and different treatments adopted in the study

\begin{tabular}{lll}
\hline Sample/treatment & Input & $\begin{array}{l}\text { Dosage } \\
(\mathrm{V} / \mathrm{V}) \\
(\%)\end{array}$ \\
\hline $\mathrm{SP}-\mathrm{dYL}$ & - & - \\
$\mathrm{SP}-\mathrm{NPK}$ & Mineral fertilizer NPK & 3.0 \\
$\mathrm{SP}-\mathrm{VRC}$ & & \\
$\mathrm{SP}-1.5 \%-\mathrm{STD}$ & Vermicompost STD & 1.5 \\
$\mathrm{SP}-3.0 \%-\mathrm{STD}$ & & 3.0 \\
$\mathrm{SP}-6.0 \%-\mathrm{STD}$ & & 6.0 \\
$\mathrm{SP}-1.5 \%-\mathrm{S}$ & Vermicompost S & 1.5 \\
$\mathrm{SP}-3.0 \%-\mathrm{S}$ & & 3.0 \\
$\mathrm{SP}-6.0 \%-\mathrm{S}$ & & 6.0 \\
$\mathrm{SP}-1.5 \%-\mathrm{C}$ & Vermicompost C & 1.5 \\
$\mathrm{SP}-3.0 \%-\mathrm{C}$ & & 3.0 \\
$\mathrm{SP}-6.0 \%-\mathrm{C}$ & & 6.0 \\
$\mathrm{SP}-1.5 \%-\mathrm{SC}$ & Vermicompost SC & 1.5 \\
$\mathrm{SP}-3.0 \%-\mathrm{SC}$ & & 3.0 \\
$\mathrm{SP}-6.0 \%-\mathrm{SC}$ & & 6.0 \\
\hline
\end{tabular}

$S P$ sweet pepper, $d Y L$ dystrophic yellow latosol, $S T D$ vermicompost control, $S$ tannery sludge, $C$ tanned chips, $S C$ mixture of tannery sludge and tanned chips 
The average flowering time was calculated by the difference in days between the appearance of the flowering and the falling of petals. The difference in days between the complete formation of the green fruit and the intense red coloration of the fruit was used to determine the mean maturation time.

The size, circumference and weight were measured of fruits that were well shaped and of appropriate color. Then, the fruits were dehydrated at $40{ }^{\circ} \mathrm{C}$ for future determinations. Fruits containing anomalies or that were malformed were counted but not measured and weighed.

The chromium concentration was quantified using an Atomic Absorption Perkin Elmer, model PINAACLE 900T (Waltham, MA, USA). Cr(III) and $\mathrm{Cr}(\mathrm{VI})$ were extracted in deionized water using mechanic agitation at $60 \mathrm{rpm}$ for $30 \mathrm{~min}$, followed by vacuum filtration.

At post-harvest, because of the addition of Cr-rich waste, $\mathrm{Cr}$ was quantified in all the organs and tissues of the plants to determine possible heavy-metal accumulation in sweet pepper. After being cropped, the plants were separated in roots, stem and stalks, leaves, and fruits. All the analyzed replicates were mixed to form a single sample, which was analyzed in triplicate.

\section{Statistical analyses}

Following one-way bootstrap ANOVA, the differences among means were evaluated using Duncan's multiple range tests at $p<0.05$. The IBM SPSS statistical software package v. 20 was used for data analyses.

\section{Results and discussion}

\section{Substrate characterization}

To determine the nutritive potential of the vermicomposts, macro- and micronutrient contents and the chemical characteristics were analyzed, as shown in Table 2 . When compared with the control vermicompost (VRC-STD), the attributes of vermicomposts produced from tannery residues (VRC-S, VRC - C and VRC - SC) related to agricultural fertility, e.g., OM, TOC, and CEC, among others, were not significantly different (ANOVA bootstrap, $p>0.05$ ).

For macronutrient contents, the VRC-STD had higher concentrations of $\mathrm{P}(0.70 \%), \mathrm{K}(3.19 \%)$ and $\mathrm{Mg}(0.78 \%)$ than tannery-based vermicomposts, whereas VRC $-\mathrm{S}$ had higher values of $\mathrm{Ca}(2.11 \%)$ and $\mathrm{S}(0.49 \%)$. The lowest $\mathrm{N}$ value $(1.32 \%)$ was in $\mathrm{VRC}-\mathrm{C}$, but the concentrations of other macronutrients were not affected. The VRC-SC had the lowest values of all vermicomposts for $\mathrm{P}(0.59 \%)$, $\mathrm{K}(0.88 \%), \mathrm{Ca}(0.52 \%)$ and $\mathrm{S}(0.36 \%)$. Although the
Table 2 Chemical characteristics of the vermicomposted tannery waste mixtures (VRC $-\mathrm{S}$, VRC $-\mathrm{C}$ and VRC $-\mathrm{SC}$ ) and control sample (VRC - STD) (mean, ANOVA bootstrap, $p<0.05, n=3$, on a dry matter basis)

\begin{tabular}{llrrr}
\hline & VRC-STD & VRC-S & VRC-C & VRC-SC \\
\hline $\mathrm{pH}$ & $8.26 \mathrm{~b}$ & $8.08 \mathrm{~b}$ & $7.67 \mathrm{a}$ & $8.57 \mathrm{c}$ \\
$\mathrm{OM}(\%)$ & $36.24 \mathrm{~b}$ & $36.98 \mathrm{~b}$ & $33.80 \mathrm{a}$ & $36.04 \mathrm{~b}$ \\
$\mathrm{TOC}(\%)$ & $21.66 \mathrm{c}$ & $17.65 \mathrm{ab}$ & $25.47 \mathrm{~cd}$ & $14.64 \mathrm{a}$ \\
$\mathrm{HA}(\%)$ & $2.07 \mathrm{~b}$ & $1.68 \mathrm{a}$ & $1.46 \mathrm{ab}$ & $1.07 \mathrm{a}$ \\
$\mathrm{CEC}\left(\mathrm{cmol}_{\mathrm{c}} \mathrm{kg}^{-1}\right)$ & $451 \mathrm{ab}$ & $459.38 \mathrm{ab}$ & $478.89 \mathrm{ab}$ & $424.48 \mathrm{a}$ \\
$\mathrm{C}: \mathrm{N} \mathrm{ratio}$ & $8.94 \mathrm{bc}$ & $8.14 \mathrm{bc}$ & $6.26 \mathrm{~b}$ & $2.68 \mathrm{a}$ \\
$\mathrm{Cr}(\mathrm{III})\left(\mathrm{mg} \mathrm{kg}^{-1}\right)$ & $<\mathrm{LOQ}$ & $4.33 \mathrm{~b}$ & $7.47 \mathrm{c}$ & $1.09 \mathrm{a}$ \\
$\mathrm{N}(\%)$ & $1.48 \mathrm{ab}$ & $1.54 \mathrm{~b}$ & $1.32 \mathrm{a}$ & $2.74 \mathrm{c}$ \\
$\mathrm{P}(\%)$ & $0.70 \mathrm{~b}$ & $0.63 \mathrm{~b}$ & $0.63 \mathrm{~b}$ & $0.59 \mathrm{ab}$ \\
$\mathrm{K}(\%)$ & $3.19 \mathrm{~cd}$ & $2.09 \mathrm{c}$ & $1.88 \mathrm{~b}$ & $0.88 \mathrm{a}$ \\
$\mathrm{Ca}(\%)$ & $1.76 \mathrm{ab}$ & $2.11 \mathrm{~b}$ & $1.49 \mathrm{a}$ & $1.38 \mathrm{a}$ \\
$\mathrm{Mg}(\%)$ & $0.78 \mathrm{~b}$ & $0.75 \mathrm{~b}$ & $0.71 \mathrm{~b}$ & $0.52 \mathrm{a}$ \\
$\mathrm{S}(\%)$ & $0.45 \mathrm{a}$ & $0.49 \mathrm{a}$ & $0.40 \mathrm{a}$ & $0.36 \mathrm{a}$ \\
$\mathrm{B}\left(\mathrm{mg} \mathrm{kg}^{-1}\right)$ & $4.90 \mathrm{a}$ & $35.01 \mathrm{~b}$ & $577.67 \mathrm{~d}$ & $145.93 \mathrm{c}$ \\
$\mathrm{Cu}\left(\mathrm{mg} \mathrm{kg}^{-1}\right)$ & $6.40 \mathrm{a}$ & $33.47 \mathrm{~b}$ & $602.28 \mathrm{~d}$ & $171.93 \mathrm{c}$ \\
$\mathrm{Mn}\left(\mathrm{mg} \mathrm{kg}^{-1}\right)$ & $2.13 \mathrm{a}$ & $35.90 \mathrm{~b}$ & $570.22 \mathrm{~d}$ & $145.74 \mathrm{c}$ \\
$\mathrm{Zn}\left(\mathrm{mg} \mathrm{kg}^{-1}\right)$ & $0.01 \mathrm{a}$ & $40.68 \mathrm{~b}$ & $499.17 \mathrm{~d}$ & $160.47 \mathrm{c}$ \\
$\mathrm{Fe}\left(\mathrm{mg} \mathrm{kg}^{-1}\right)$ & $1462.10 \mathrm{a}$ & $1605.11 \mathrm{ab}$ & $1455.80 \mathrm{a}$ & $1614.03 \mathrm{ab}$ \\
\hline
\end{tabular}

$V R C$ vermicompost, $S T D$ sample control, $S$ tannery sludge, $C$ tanned chips, $S C$ mixture of tannery sludge and tanned chips, $O M$ organic matter, TOC total organic carbon, HA humic acids, CEC cation exchange capacity

Values in the same row followed by the same letter are not significantly different at $p<0.05$ according to Duncan's test

determined values were different, the concentrations did not exceed $1.00 \%$ (Table 2).

When micronutrient contents were compared, the differences were extreme (Table 2). Except for Fe, the concentrations of micronutrients in $\mathrm{VRC}-\mathrm{C}$ always greatly exceeded those in the others: $\mathrm{B}\left(577.67 \mathrm{mg} \mathrm{kg}^{-1}\right)$, $\mathrm{Cu}\left(602.28 \mathrm{mg} \mathrm{kg}^{-1}\right), \mathrm{Mn}\left(570.22 \mathrm{mg} \mathrm{kg}^{-1}\right)$ and $\mathrm{Zn}$ (499.17 $\left.\mathrm{mg} \mathrm{kg}^{-1}\right)$, i.e., values approximately fivefold higher than those determined in VRC-SC. However, the values observed in these two vermicompost types were up to 10,000-fold greater than concentrations determined in the VRC-STD and VRC-S. Therefore, micronutrient quantities were found from high to low as follows: $\mathrm{VRC}-\mathrm{C}>\mathrm{VRC}-\mathrm{SC}>\mathrm{VRC}-\mathrm{S}>\mathrm{VRC}-\mathrm{STD}$.

For the content of $\mathrm{Cr}$, as expected, VRC-STD had values of $\mathrm{Cr}$ (III) and $\mathrm{Cr}$ (VI) below the detectable level (LOQ, $79.80 \mu \mathrm{g} \mathrm{kg}^{-1}$ ). In the vermicomposts containing tannery residues, the concentrations of $\mathrm{Cr}(\mathrm{III})$ were $\mathrm{VRC}-\mathrm{C}$ at $7.47 \mathrm{mg} \mathrm{kg}^{-1}$, VRC $-\mathrm{S}$ at $4.33 \mathrm{mg} \mathrm{kg}^{-1}$ and VRC-SC at $1.09 \mathrm{mg} \mathrm{kg}^{-1}$, with all values significantly different (ANOVA bootstrap, $p<0.05$ ). For $\mathrm{Cr}(\mathrm{VI})$, this form was not detected in any vermicompost (Table 2). 


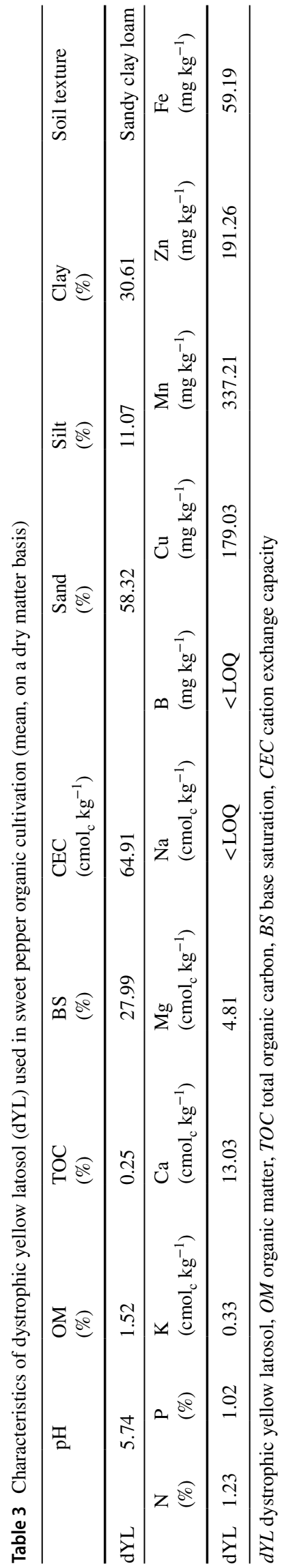

Table 4 Sweet pepper plant development on different cultivation substrates ( $\mathrm{SP}-\mathrm{STD}, \mathrm{SP}-\mathrm{S}, \mathrm{SP}-\mathrm{C}$ and $\mathrm{SP}-\mathrm{SC}$ ), the reference sample $(\mathrm{SP}-\mathrm{NPK})$ and the control sample $(\mathrm{SP}-\mathrm{dYL})$ (mean, ANOVA bootstrap, $p<0.05, n=3$ )

\begin{tabular}{llll}
\hline & Height ${ }^{\mathrm{a}}(\mathrm{cm})$ & $\begin{array}{l}\text { Number of } \\
\text { leaves }^{\mathrm{b}}\end{array}$ & Leaf area ${ }^{\mathrm{b}}\left(\mathrm{cm}^{2}\right)$ \\
\hline SP-dYL & $12.7 \mathrm{a}$ & \multicolumn{1}{c}{$7.6 \mathrm{a}$} & $8.33 \mathrm{a}$ \\
SP-NPK & $19.0 \mathrm{a}$ & $22.3 \mathrm{ab}$ & $29.80 \mathrm{bc}$ \\
SP-1.5\%-STD & $32.0 \mathrm{~cd}$ & $28.3 \mathrm{bcd}$ & $27.24 \mathrm{c}$ \\
SP-3.0\%-STD & $34.0 \mathrm{~cd}$ & $35.3 \mathrm{bcde}$ & $43.12 \mathrm{~cd}$ \\
SP-6.0\%-STD & $41.0 \mathrm{de}$ & $37.6 \mathrm{cde}$ & $60.73 \mathrm{de}$ \\
SP-1.5\%-S & $24.7 \mathrm{bc}$ & $20.6 \mathrm{ab}$ & $23.82 \mathrm{~b}$ \\
SP-3.0\%-S & $30.3 \mathrm{c}$ & $28.0 \mathrm{bcd}$ & $30.93 \mathrm{bc}$ \\
SP-6.0\%-S & $43.7 \mathrm{e}$ & $47.0 \mathrm{e}$ & $66.43 \mathrm{ef}$ \\
SP-1.5\%-C & $32.0 \mathrm{~cd}$ & $26.6 \mathrm{bcd}$ & $31.27 \mathrm{bc}$ \\
SP-3.0\%-C & $45.0 \mathrm{e}$ & $39.3 \mathrm{de}$ & $55.26 \mathrm{de}$ \\
SP-6.0\%-C & $49.7 \mathrm{e}$ & $46.6 \mathrm{e}$ & $79.50 \mathrm{f}$ \\
SP-1.5\%-SC & $25.7 \mathrm{bc}$ & $25.6 \mathrm{bcd}$ & $24.69 \mathrm{bc}$ \\
SP-3.0\%-SC & $44.0 \mathrm{e}$ & $48.6 \mathrm{ef}$ & $67.91 \mathrm{ef}$ \\
SP-6.0\%-SC & $49.7 \mathrm{e}$ & $62.3 \mathrm{f}$ & $128.35 \mathrm{~g}$
\end{tabular}

$S P$ sweet pepper, $d Y L$ dystrophic yellow latosol, $S T D$ vermicompost control, $S$ tannery sludge, $C$ tanned chips, $S C$ mixture of tannery sludge and tanned chips

Values in the same column followed by the same letter are not significantly different at $p<0.05$ according to Duncan's test

${ }^{\text {a After }} 120$ days of cultivation (post-harvest)

${ }^{\mathrm{b}}$ After 45 days of cultivation

\section{Sweet pepper cultivation}

The attributes of the latosol were typical of a dYL soil (EMBRAPA 2018), i.e., acidic with a pH of 5.74, poor OM content of $1.52 \%$, TOC of $0.25 \%$, CEC of $64.91 \mathrm{cmol}_{\mathrm{c}} \mathrm{kg}^{-1}$, and small base saturation of BS $27.99 \%$. For soil particle size distribution, the texture of the dYL was classified as sandy clay loam, with $31.00 \%$ clay, $11.00 \%$ silt and $58.00 \%$ sand (Table 3 ).

For nutrients, the dYL had low levels of essential elements for plants (Table 3). Therefore, the dYL did not satisfy the nutritional requirements for cultivation for agricultural production, with low levels of the exchangeable bases: $\mathrm{K}\left(0.33 \mathrm{cmol}_{\mathrm{c}} \mathrm{kg}^{-1}\right), \mathrm{Ca}\left(13.03 \mathrm{cmol}_{\mathrm{c}} \mathrm{kg}^{-1}\right)$ and $\mathrm{Mg}\left(4.81 \mathrm{cmol}_{\mathrm{c}} \mathrm{kg}^{-1}\right)$. For micronutrients, the concentrations from high to low were $\mathrm{Mn}\left(337.21 \mathrm{mg} \mathrm{kg}^{-1}\right)$, $\mathrm{Zn}\left(191.26 \mathrm{mg} \mathrm{kg}^{-1}\right), \mathrm{Cu}\left(179.03 \mathrm{mg} \mathrm{kg}^{-1}\right)$ and $\mathrm{Fe}$ $\left(59.19 \mathrm{mg} \mathrm{kg}^{-1}\right)$. Levels of $\mathrm{Na}$ and some other micronutrients were below the detectable level (LOQ) (Table 3).

Poor in OM and with low CEC and nutrients, the dYL was ideally suited to evaluate the nutritive potential of the vermicomposts. A soil rich in OM could confound interpretation of the results following vermicompost application because the effects of soil OM and OM added from 
the vermicompost on plant nutrition cannot be discerned individually. Additionally, incorporating $\mathrm{OM}$ into soil leads to improved CEC and BS, in addition to increasing TOC levels, which are fundamental attributes for soil quality in agricultural systems (Ndegwa et al. 2000; Canellas and Santos 2005; Tobiašová 2011).

Criteria were established for the transfer of seedlings from the trays to the plastic pots and then to the cultivation vessels: 5- and 10-cm height, respectively. Approximately, 7 and 30 days passed for each transplant, respectively.

In general, plants from the SP-dYL and SP-NPK treatments had distinctly less development compared with those from SP-VRC. Plants grown on substrates containing vermicomposts showed more growth and more fruits were produced, with better appearance and greater weight and dimensions. Generally, as the amount of vermicompost increased, the yield (number of fruits) and plant health (visual analysis) increased.

The development of sweet pepper plants in SP-dYL and SP-NPK (control and reference treatments) was similar; however, fruits were only produced on plants in the $\mathrm{SP}-\mathrm{NPK}$ treatment. Although vermicomposts with different compositions have been examined in previous studies, similarly satisfactory results have been reported (Bachman and Metzger 2008; Kaur et al. 2010; Vig et al. 2011; Kenyangi and Blok 2013; Nunes et al. 2016). Data related to the development of sweet pepper plants (e.g., growth, nutritive value, and fruit production, among others) obtained in this study are discussed below.

Plant growth in treatments SP-dYL and SP-NPK was not significantly different at 12.7 and $19.0 \mathrm{~cm}$, respectively (ANOVA bootstrap, $p<0.05$; Table 4 ). Therefore, the addition of NPK fertilizer did not significantly affect plant growth. Plant growth in the control and reference treatments was significantly different from all treatments in the SPVRC group at all studied concentrations (ANOVA bootstrap, $p<0.05$ ).

Plants cultivated with the control vermicompost (VRCSTD) added at 1.5\%, 3.0\% and 6.0\% did not show significant differences in growth (ANOVA bootstrap, $p<0.05$ ), after 120 days of the experiment. The difference in plant growth was $\sim 6-28 \%$, with mean growth between 32.0 and $41.0 \mathrm{~cm}$ (Table 4).

Analyzing plant growth under application of the vermicompost $\mathrm{S}$, the mean growth of plants in treatments $\mathrm{SP}-1.5 \%-\mathrm{S}$ and $\mathrm{SP}-3.0 \%-\mathrm{S}$ was not significantly different at 24.7 and $30.3 \mathrm{~cm}$, respectively. However, both levels of growth were significantly different compared with that of plants in the treatment $\mathrm{SP}-6.0 \%-\mathrm{S}$, with growth of $43.7 \mathrm{~cm}$ (ANOVA bootstrap, $p<0.05$; Table 4 ).

When vermicompost $\mathrm{C}$ was applied, mean plant growth in treatments $\mathrm{SP}-3.0 \%-\mathrm{C}$ and $\mathrm{SP}-6.0 \%-\mathrm{C}$ was 45.0 and $49.7 \mathrm{~cm}$, respectively, which were not significantly different.
Plants in the treatment $\mathrm{SP}-1.5 \%-\mathrm{C}$ grew $32.0 \mathrm{~cm}$, which was significantly different from growth in the other levels of vermicompost C (ANOVA bootstrap, $p<0.05$ ). At all concentrations, plant growth in the SP-SC treatments was not significantly different compared with that in the SP-C treatments (Table 4).

In general, the growth of all plants that received 1.5\% vermicompost was not significantly different (ANOVA bootstrap, $p>0.05$ ). Among all treatments, plants with the highest growth were in $\mathrm{SP}-6.0 \%-\mathrm{C}$ and $\mathrm{SP}-6.0 \%-\mathrm{SC}$, both at $\sim 49 \mathrm{~cm}$. In samples from the group SP-VRC, plant growth was proportional to vermicompost concentration, with growth at $1.5 \%<3.0 \%<6.0 \%$ (Table 4 ).

Data related to the leaves (e.g., number, area, and nutritive value) were important to monitor and to qualify in the development of sweet pepper plants in different types of substrate. From the beginning of the experiment $(\sim 15$ days after planting), the uniqueness in the dimensions of leaves could be observed. After 45 days, whereas the size of leaves from the SP- $-\mathrm{YL}$ and $\mathrm{SP}-\mathrm{NPK}$ treatments remained with the same, leaves in the SP-6.0\%-SC treatments had dimensions that were larger than a hand. For the leaf area $(A)$, after 60 days, the area of leaves in SP-dYL was significantly smaller than that in the other treatments $\left(8.33 \mathrm{~cm}^{2}\right)$. In SPNPK and SP-1.5\% - VRC treatments, the areas of leaves were not significantly different, with values varying between 23.82 and $31.27 \mathrm{~cm}^{2}$ (ANOVA bootstrap, $p<0.05$; Table 4).

In general, the nutrient contents in the leaves varied randomly, without tending to the expected. As the sweet pepper continued to develop, the concentrations of nutrients decreased as expected, primarily because of ion dilution in the tissues and organs of the plants (Tables 5 and 6) (Malavolta 1980; Malavolta et al. 1997); however, exceptions were observed.

Nutrients directly influenced plant development, as demonstrated by sweet pepper growth and production. Additionally, visual assessment of the plants, based primarily on the color, shape and texture of leaves, provided important information on the nutritional statuses of the plants (Malavolta 1980; Epstein 1997; Faquin 2005; Epstein and Bloom 2006; Fontes 2006).

Concerning the appearance of leaves, a yellowing was observed in plants of the SP-dYL treatment after 5 days of cultivation that persisted for the entire experiment, with the same occurring after 45 days for plants of the group SP-1.5\%-VRC. At concentrations of $3.0 \%$ and $6.0 \%$ vermicompost, the yellowing occurred at 75 and 90 days of cultivation, respectively. In the SP-NPK treatment, no change was observed in leaf color throughout the experiment. Although the application of mineral fertilizer did not contribute significantly to plant development, nutrition was guaranteed at all plant developmental stages. 
Table 5 Leaf

analysis (macronutrients) on sweet pepper leaves cultivated on different substrates ( $\mathrm{SP}-$ $\mathrm{STD}, \mathrm{SP}-\mathrm{S}, \mathrm{SP}-\mathrm{C}$ and $\mathrm{SP}-$ $\mathrm{SC})$, the reference sample (SPNPK) and the control sample (SP-dYL) (mean, ANOVA bootstrap, $p<0.05, n=3)$
Table 6 Leaf analysis (micronutrients) on sweet pepper leaves cultivated on different substrates ( $\mathrm{SP}$ $\mathrm{STD}, \mathrm{SP}-\mathrm{S}, \mathrm{SP}-\mathrm{C}$ and $\mathrm{SP}-$ $\mathrm{SC}$ ), the reference sample (SPNPK) and the control sample (SP-dYL) (mean, ANOVA bootstrap, $p<0.05, n=3$ )

\begin{tabular}{lllllll}
\hline & $\mathrm{N}(\%)$ & $\mathrm{P}(\%)$ & $\mathrm{K}(\%)$ & $\mathrm{Ca}(\%)$ & $\mathrm{Mg}(\%)$ & $\mathrm{S}(\%)$ \\
\hline $\mathrm{SP}-\mathrm{dYL}$ & $1.97 \mathrm{ab}$ & $0.25 \mathrm{a}$ & $5.71 \mathrm{~b}$ & $1.67 \mathrm{a}$ & $0.24 \mathrm{a}$ & $1.03 \mathrm{~b}$ \\
$\mathrm{SP}-\mathrm{NPK}$ & $2.29 \mathrm{~b}$ & $0.41 \mathrm{a}$ & $5.71 \mathrm{~b}$ & $2.99 \mathrm{bc}$ & $0.73 \mathrm{ab}$ & $0.79 \mathrm{ab}$ \\
$\mathrm{SP}-1.5 \%-\mathrm{STD}$ & $2.14 \mathrm{~b}$ & $0.44 \mathrm{a}$ & $6.63 \mathrm{~b}$ & $2.22 \mathrm{ab}$ & $0.58 \mathrm{ab}$ & $0.81 \mathrm{ab}$ \\
$\mathrm{SP}-3.0 \%-\mathrm{STD}$ & $1.93 \mathrm{ab}$ & $0.47 \mathrm{ab}$ & $6.58 \mathrm{~b}$ & $1.85 \mathrm{a}$ & $0.43 \mathrm{a}$ & $0.83 \mathrm{ab}$ \\
$\mathrm{SP}-6.0 \%-\mathrm{STD}$ & $2.18 \mathrm{~b}$ & $0.22 \mathrm{a}$ & $5.41 \mathrm{~b}$ & $3.57 \mathrm{c}$ & $0.71 \mathrm{ab}$ & $1.03 \mathrm{~b}$ \\
$\mathrm{SP}-1.5 \%-\mathrm{S}$ & $1.83 \mathrm{ab}$ & $0.32 \mathrm{a}$ & $5.01 \mathrm{~b}$ & $3.11 \mathrm{c}$ & $0.71 \mathrm{ab}$ & $1.14 \mathrm{bc}$ \\
$\mathrm{SP}-3.0 \%-\mathrm{S}$ & $1.80 \mathrm{ab}$ & $0.48 \mathrm{ab}$ & $5.42 \mathrm{~b}$ & $3.04 \mathrm{c}$ & $0.64 \mathrm{ab}$ & $1.05 \mathrm{~b}$ \\
$\mathrm{SP}-6.0 \%-\mathrm{S}$ & $1.50 \mathrm{a}$ & $0.67 \mathrm{~b}$ & $5.73 \mathrm{~b}$ & $2.13 \mathrm{ab}$ & $0.51 \mathrm{a}$ & $0.92 \mathrm{ab}$ \\
$\mathrm{SP}-1.5 \%-\mathrm{C}$ & $1.58 \mathrm{a}$ & $0.20 \mathrm{a}$ & $5.85 \mathrm{~b}$ & $2.13 \mathrm{ab}$ & $0.65 \mathrm{ab}$ & $0.85 \mathrm{ab}$ \\
$\mathrm{SP}-3.0 \%-\mathrm{C}$ & $1.85 \mathrm{ab}$ & $0.51 \mathrm{a}$ & $5.62 \mathrm{~b}$ & $2.48 \mathrm{~b}$ & $0.67 \mathrm{ab}$ & $0.94 \mathrm{ab}$ \\
$\mathrm{SP}-6.0 \%-\mathrm{C}$ & $1.99 \mathrm{ab}$ & $0.65 \mathrm{~b}$ & $5.71 \mathrm{~b}$ & $2.17 \mathrm{ab}$ & $0.66 \mathrm{ab}$ & $0.72 \mathrm{a}$ \\
$\mathrm{SP}-1.5 \%-\mathrm{SC}$ & $1.54 \mathrm{a}$ & $0.23 \mathrm{a}$ & $2.58 \mathrm{a}$ & $2.26 \mathrm{ab}$ & $0.58 \mathrm{ab}$ & $0.71 \mathrm{a}$ \\
$\mathrm{SP}-3.0 \%-\mathrm{SC}$ & $1.69 \mathrm{a}$ & $0.18 \mathrm{a}$ & $2.56 \mathrm{a}$ & $2.10 \mathrm{ab}$ & $0.62 \mathrm{ab}$ & $0.78 \mathrm{a}$ \\
$\mathrm{SP}-6.0 \%-\mathrm{SC}$ & $1.74 \mathrm{ab}$ & $0.24 \mathrm{a}$ & $2.16 \mathrm{a}$ & $2.04 \mathrm{ab}$ & $0.65 \mathrm{ab}$ & $0.76 \mathrm{a}$ \\
\hline
\end{tabular}

$S P$ sweet pepper, $d Y L$ dystrophic yellow latosol, $S T D$ vermicompost control, $S$ tannery sludge, $C$ tanned chips, $S C$ mixture of tannery sludge and tanned chips

Values in the same column followed by the same letter are not significantly different at $p<0.05$ according to Duncan's test

\begin{tabular}{lcllcc}
\hline & $\mathrm{B}\left(\mathrm{mg} \mathrm{kg}^{-1}\right)$ & $\mathrm{Cu}\left(\mathrm{mg} \mathrm{kg}^{-1}\right)$ & $\mathrm{Mn}\left(\mathrm{mg} \mathrm{kg}^{-1}\right)$ & $\mathrm{Zn}\left(\mathrm{mg} \mathrm{kg}^{-1}\right)$ & $\mathrm{Fe}\left(\mathrm{mg} \mathrm{kg}^{-1}\right)$ \\
\hline SP-dYL & $88.25 \mathrm{~b}$ & 1.36 & $294.63 \mathrm{bc}$ & $100.30 \mathrm{ab}$ & $1223.76 \mathrm{c}$ \\
SP-NPK & $89.75 \mathrm{~b}$ & 2.88 & $353.97 \mathrm{c}$ & $107.93 \mathrm{ab}$ & $1002.25 \mathrm{c}$ \\
SP-1.5\%-STD & $85.04 \mathrm{~b}$ & 0.13 & $157.44 \mathrm{a}$ & $99.93 \mathrm{ab}$ & $738.69 \mathrm{a}$ \\
SP-3.0\%-STD & $72.65 \mathrm{ab}$ & 0.23 & $133.19 \mathrm{a}$ & $88.09 \mathrm{a}$ & $577.78 \mathrm{a}$ \\
SP-6.0\%-STD & $164.12 \mathrm{c}$ & 1.44 & $375.32 \mathrm{c}$ & $145.84 \mathrm{~b}$ & $1316.88 \mathrm{~d}$ \\
SP-1.5\%-S & $116.46 \mathrm{c}$ & 0.57 & $211.31 \mathrm{~b}$ & $99.25 \mathrm{a}$ & $1762.12 \mathrm{e}$ \\
SP-3.0\%-S & $104.06 \mathrm{c}$ & 0.54 & $203.55 \mathrm{~b}$ & $102.22 \mathrm{ab}$ & $1264.24 \mathrm{c}$ \\
SP-6.0\%-S & $57.26 \mathrm{a}$ & 1.97 & $127.09 \mathrm{a}$ & $102.95 \mathrm{ab}$ & $858.62 \mathrm{~b}$ \\
SP-1.5\%-C & $88.68 \mathrm{~b}$ & $\mathrm{n} . \mathrm{d}$. & $277.32 \mathrm{~b}$ & $104.61 \mathrm{ab}$ & $762.32 \mathrm{a}$ \\
$\mathrm{SP}-3.0 \%-\mathrm{C}$ & $76.07 \mathrm{ab}$ & 0.64 & $100.14 \mathrm{a}$ & $102.91 \mathrm{ab}$ & $813.51 \mathrm{ab}$ \\
SP-6.0\%-C & $50.64 \mathrm{a}$ & 0.04 & $245.17 \mathrm{~b}$ & $101.82 \mathrm{ab}$ & $861.84 \mathrm{~b}$ \\
SP-1.5\%-SC & $78.21 \mathrm{ab}$ & 0.67 & $492.57 \mathrm{~d}$ & $143.87 \mathrm{~b}$ & 1091.23 \\
SP-3.0\%-SC & $58.54 \mathrm{a}$ & 0.29 & $356.25 \mathrm{c}$ & $94.47 \mathrm{a}$ & $812.90 \mathrm{ab}$ \\
SP-6.0\%-SC & $67.95 \mathrm{a}$ & 0.11 & $305.76 \mathrm{c}$ & $125.56 \mathrm{~b}$ & $527.06 \mathrm{a}$ \\
\hline
\end{tabular}

$S P$ sweet pepper, $d Y L$ dystrophic yellow latosol, $S T D$ vermicompost control, $S$ tannery sludge, $C$ tanned chips, $S C$ mixture of tannery sludge and tanned chips

Values in the same column followed by the same letter are not significantly different at $p<0.05$ according to Duncan's test
For plants that received the vermicompost control, leaf area in the SP-1.5\%-STD treatment $\left(27.24 \mathrm{~cm}^{2}\right)$ was significantly different from that of the others $\left(43.12 \mathrm{~cm}^{2}\right.$ in SP-3.0\%-STD and $60.73 \mathrm{~cm}^{2}$ in SP-6.0\%-STD), with the difference between the two higher levels not significant. Leaf area of plants from $\mathrm{SP}-\mathrm{C}$ and $\mathrm{SP}-\mathrm{SC}$ treatments was not significantly different and their leaves had the largest dimensions and therefore areas (ANOVA bootstrap, $p<0.05$ ).

For macronutrients (Table 5), in a comparison between the control and reference treatments $(\mathrm{SP}-\mathrm{dYL}$ and $\mathrm{SP}-$ NPK, respectively), the concentrations in plants from SPNPK were higher than those in the control, as expected. However, concentrations of K $(5.71 \%)$ and S $(0.79 \%)$ were the exceptions and were below those of plants in SP-dYL. 
Furthermore, the addition of N, P and $\mathrm{K}$ from the mineral fertilizer did not guarantee the highest concentrations of these nutrients among treatments, except for $\mathrm{N}(2.29 \%)$. The highest value of $\mathrm{P}$ was determined in $\mathrm{SP}-6.0 \%-\mathrm{S}$ $(0.67 \%)$ and that of $\mathrm{K}$ in SP-1.5\% - STD (6.63\%). The lowest concentrations of macronutrients were in $\mathrm{SP}-\mathrm{C}$ and SP-SC treatments, with the lowest values of $\mathrm{P}(0.18 \%$ in $\mathrm{SP}-3.0 \%-\mathrm{SC}), \mathrm{K}(2.16 \%$ in $\mathrm{SP}-6.0 \%-\mathrm{SC})$ and $\mathrm{S}$ ( $0.71 \%$ in $\mathrm{SP}-1.5 \%$ - SC), most likely due to ion dilution in the plant tissues (Malavolta 1980; Malavolta et al. 1997).

Concerning the micronutrients (Table 6), the highest concentrations were in plants from the SP-6.0\%-STD treatment, with high levels of B $\left(164.12 \mathrm{mg} \mathrm{kg}^{-1}\right), \mathrm{Zn}$ (145.84 $\mathrm{mg} \mathrm{kg}^{-1}$ ) and $\mathrm{Fe}\left(1316.88 \mathrm{mg} \mathrm{kg}^{-1}\right)$; and in the plants from SP-SC treatments, with high levels of $\mathrm{Cu}$ (29.64 mg kg${ }^{-1}$ in SP-3.0\%-SC) and Mn (492.57 mg kg-1 in $\mathrm{SP}-3.0 \%-\mathrm{SC}$ ). With the exceptions of $\mathrm{Zn}$ and $\mathrm{Fe}$, the lowest concentrations of micronutrients were in plants from the $\mathrm{SP}-\mathrm{C}$ treatments: $\mathrm{B}\left(50.64 \mathrm{mg} \mathrm{kg}^{-1}\right)$ and $\mathrm{Cu}$ $\left(0.04 \mathrm{mg} \mathrm{kg}^{-1}\right)$ in SP-6.0\%-C; and $\mathrm{Mn}\left(100.14 \mathrm{mg} \mathrm{kg}^{-1}\right)$ in $\mathrm{SP}-3.0 \%-\mathrm{C}$.

Consistent with our findings, many studies have demonstrated the effects of nutrients on growth, development and fruit production in sweet pepper (Malavolta 1980; Marti and Mills 1991; Aguilera-Gomez et al. 1999; Riga and Anza 2003; Faquin 2005; Albuquerque et al. 2011).

Marti and Mills (1991) studied the effects of Ca uptake by roots on plant growth and development, in addition to its correlation with the $\mathrm{N}$ concentration in the substrate. Albuquerque et al. (2011) studied the effect of the soil K concentration on the production of red sweet pepper, in addition to that on biometric fruit data. Riga and Anza (2003) evaluated the effects of Mg deficiency on the physiology of pepper plants and found that it affected plant growth and development. Moreover, Aguilera-Gomez et al. (1999), among other studies, examined the effects of P uptake on the development of sweet pepper plants. Overall, vermicomposts clearly sufficiently nourished the sweet pepper plants to promote their growth, development and fruit production.

Fruit production (red sweet pepper, at the mature stage), in addition to fruit characteristics (dimensions, weight and appearance), are important attributes for evaluating the effects of vermicompost addition on sweet pepper cultivation. In general, the addition of vermicompost was a biostimulant to the plants in this study, increasing the number and quality of cropped fruits (Table 7).

Regarding production, plants subjected to the control treatment $(\mathrm{SP}-\mathrm{dYL})$ did not produce any fruit, whereas those exposed to the reference treatment (SP-NPK) produced only one harvested fruit per plant. The optimum results were obtained for the plants exposed to the $\mathrm{SP}-3.0 \%$ - SC and SP-6.0\% - SC treatments, which produced three fruits per plant. In addition, the plants subjected to the SP-6.0\%-S, SP-3.0\%-C, and SP-6.0\%-C treatments produced two fruits. For the other treatments, the plants only produced one fruit (Table 7).

Some plants also produced red sweet peppers that did not meet esthetic standards, with irregular shape and coloration, resulting in no commercial value. The worst results were observed for plants in the treatments of group SP-STD
Table 7 Red sweet pepper production on different substrates (SP-STD, SP-S, $\mathrm{SP}-\mathrm{C}$ and $\mathrm{SP}-\mathrm{SC})$, the reference sample (SP-NPK) and the control sample (SP-dYL) (mean, ANOVA bootstrap, $p<0.05, n=3$ )

\begin{tabular}{|c|c|c|c|c|c|}
\hline & \multirow{2}{*}{$\begin{array}{l}\text { Fruit production } \\
\text { (fruit plant }^{-1} \text { ) }\end{array}$} & \multirow{2}{*}{$\begin{array}{l}\text { Time forma- } \\
\text { tion (days) }\end{array}$} & \multicolumn{3}{|c|}{ Fruit characteristics } \\
\hline & & & Size $(\mathrm{cm})$ & Circumference $(\mathrm{cm})$ & Weight (g) \\
\hline $\mathrm{SP}-\mathrm{dYL}$ & $0 \mathrm{a}$ & - & - & - & - \\
\hline $\mathrm{SP}-\mathrm{NPK}$ & $1 \mathrm{bcd}$ & $94 \mathrm{a}$ & $11.3 \mathrm{bcd}$ & $19.1 \mathrm{cde}$ & $96.8 \mathrm{bcd}$ \\
\hline $\mathrm{SP}-1.5 \%-\mathrm{STD}$ & $1 \mathrm{bcd}$ & $121 \mathrm{bcde}$ & $10.7 \mathrm{bcd}$ & $13.3 \mathrm{abc}$ & $46.7 \mathrm{abc}$ \\
\hline $\mathrm{SP}-3.0 \%-\mathrm{STD}$ & $1 \mathrm{~cd}$ & $105 \mathrm{abcd}$ & $11.9 \mathrm{~cd}$ & 17.0abcd & $93.0 \mathrm{bcd}$ \\
\hline $\mathrm{SP}-6.0 \%-\mathrm{STD}$ & $1 \mathrm{~cd}$ & $87 a$ & $10.9 \mathrm{bcd}$ & $18.8 \mathrm{bcde}$ & $134.5 \mathrm{~d}$ \\
\hline $\mathrm{SP}-1.5 \%-\mathrm{S}$ & $1 \mathrm{bcd}$ & $126 \mathrm{e}$ & $6.2 \mathrm{a}$ & $11.2 \mathrm{a}$ & $23.1 \mathrm{a}$ \\
\hline $\mathrm{SP}-3.0 \%-\mathrm{S}$ & $1 \mathrm{~cd}$ & $123 \mathrm{de}$ & $8.6 \mathrm{abc}$ & $14.7 \mathrm{abcd}$ & $47.0 \mathrm{abc}$ \\
\hline $\mathrm{SP}-6.0 \%-\mathrm{S}$ & $1 \mathrm{~cd}$ & $91 \mathrm{ab}$ & $12.4 \mathrm{~d}$ & $23.0 \mathrm{e}$ & $107.0 \mathrm{~cd}$ \\
\hline $\mathrm{SP}-1.5 \%-\mathrm{C}$ & $1 \mathrm{bcd}$ & 110bcde & $8.0 \mathrm{ab}$ & $13.3 \mathrm{abc}$ & $37.0 \mathrm{ab}$ \\
\hline $\mathrm{SP}-3.0 \%-\mathrm{C}$ & $2 \mathrm{de}$ & $92 \mathrm{ab}$ & $11.7 \mathrm{bcd}$ & $14.5 \mathrm{abcd}$ & $84.6 \mathrm{bcd}$ \\
\hline $\mathrm{SP}-6.0 \%-\mathrm{C}$ & $2 \mathrm{de}$ & $100 \mathrm{abc}$ & $12.5 \mathrm{~d}$ & $19.8 \mathrm{de}$ & $113.3 \mathrm{~d}$ \\
\hline $\mathrm{SP}-1.5 \%-\mathrm{SC}$ & $1 \mathrm{bc}$ & $120 \mathrm{cde}$ & $6.0 \mathrm{a}$ & $13.0 \mathrm{ab}$ & $24.8 \mathrm{a}$ \\
\hline $\mathrm{SP}-3.0 \%-\mathrm{SC}$ & $3 \mathrm{e}$ & $97 \mathrm{ab}$ & $11.2 \mathrm{bcd}$ & $17.2 \mathrm{bcd}$ & $86.7 \mathrm{bcd}$ \\
\hline $\mathrm{SP}-6.0 \%-\mathrm{SC}$ & $3 e$ & $87 \mathrm{a}$ & $10.5 \mathrm{bcd}$ & $19.0 \mathrm{bcde}$ & $100.8 \mathrm{~cd}$ \\
\hline
\end{tabular}

$S P$ sweet pepper, $d Y L$ dystrophic yellow latosol, $S T D$ vermicompost control, $S$ tannery sludge, $C$ tanned chips, $S C$ mixture of tannery sludge and tanned chips

Values in the same column followed by the same letter are not significantly different at $p<0.05$ according to Duncan's test 
because for each two well-formed fruits, one fruit was an anomaly (50\% of production). Some treatments showed a significantly higher proportion of well-formed fruits, including in SP-6.0\% - SC (5:1 ratio), with only two of ten total fruits showing anomalies, and in $\mathrm{SP}-3.0 \%-\mathrm{SC}$ (ratio 8:0), SP-6.0\%-C (ratio 6:0), and $\mathrm{SP}-3.0 \%-\mathrm{C}$ (ratio 4:1) (ANOVA bootstrap, $p<0.05$ ). Plants exposed to some of the treatments showed only well-formed fruits, i.e., $\mathrm{SP}-6.0 \%-\mathrm{C}, \mathrm{SP}-3.0 \%-\mathrm{SC}$ and the reference treatment, SP-NPK (Table 7).

For fruit formation, less time was required for formation and maturation of red sweet peppers as the vermicompost concentration increased, except for the plants in the SP-C treatments, which all had maturation times between 92 and 110 days that were not significantly different (ANOVA bootstrap, $p<0.05$ ). Additionally, plants in all the treatments with $6.0 \%$ vermicompost, some treatments with $3.0 \%$ (i.e., $\mathrm{SP}-3.0 \%-\mathrm{STD}, \mathrm{SP}-3.0 \%-\mathrm{C}$ and SP-3.0\%-SC) and the SP-NPK reference treatment showed maturation times that were not significantly different at $87-105$ days (ANOVA bootstrap, $p<0.05$, Table 7).

In general, fruits with shorter maturation times had higher weights, varying between 100.8 and $134.5 \mathrm{~g}$, with no significant differences (ANOVA bootstrap, $p<0.05$ ). Fruits obtained on plants from treatments with $1.5 \%$ vermicompost had fruits that weighed between 23.1 and $46.7 \mathrm{~g}$, with values that were significantly different (ANOVA bootstrap, $p<0.05)$. The difference between fruit weights in the treatments SP-STD and SP-VRC was approximately $480 \%$, indicating the biostimulant effect of vermicompost application on fruit production and attributes.

Concerning the dimensions of fruits, a relation between size and circumference could not be established because larger fruits could have a smaller circumference and vice versa. In general, plants that received $3.0 \%$ and $6.0 \%$ vermicompost produced fruits with the largest dimensions, varying between 10.5 and $12.5 \mathrm{~cm}$ in size and 17.0 and $23.0 \mathrm{~cm}$ in circumference, with no significant differences (ANOVA bootstrap, $p<0.05)$. In the treatments that received $1.5 \%$ vermicompost, the fruit size and circumference ranged between 6.0 and $8.0 \mathrm{~cm}$ and 11.2 and $13.3 \mathrm{~cm}$, respectively (Table 7).

Ribeiro et al. (2000) studied the use of vermicomposts as an alternative for the organic production of sweet pepper in a protected environment. Additionally, the authors compared their results with experiments using a eutrophic red argisol (eRA) and under the application of NPK, imitating a conventional plantation. Although the structure and design of their study were similar to those of this study, the soil selected was different. An eRA (4.26\% OM) could mask the results and influence of vermicompost on sweet pepper development because this soil had a certain nutritional potential, different from that of the dYL (EMBRAPA 2018). These findings are similar to those observed in our study. However, in that study, plants that received vermicompost had better results than those planted with NPK and in the control soil based on the following: (1) in organic cultivation (with vermicompost), the production was $16.0 \mathrm{t} \mathrm{ha}^{-1}$, whereas in the conventional planting, production was below $13.1 \mathrm{tha}^{-1}$; (2) the production in the control treatment (eRA) was below that obtained in organic cultivation but above that in conventional planting at $13.60 \mathrm{tha}^{-1}$; and (3) organic sweet peppers had an average weight of $72.9 \mathrm{~g}$, compared with $67.8 \mathrm{~g}$ in the conventional and $65.5 \mathrm{~g}$ in eRA treatments.

In a comparison of studies, the fruit weight (84.6-134.5 g), for example, when $3.0 \%$ and $6.0 \%$ vermicompost were applied in our study, was notably higher than the $72.9 \mathrm{~g}$ found by Ribeiro et al. (2000). For fruit size, our organic sweet peppers also had larger dimensions, $9.3 \mathrm{~cm}$ in circumference, than the $9.0-$ and $8.9-\mathrm{cm}$ circumferences found in the conventional cultivation and in eRA, respectively. Although our results were apparently superior, both studies indicated the efficacy and viability of the use of vermicompost in systems of organic agriculture and sweet pepper cultivation.

In general, because of the variety of soils in Brazil and the wide availability of agricultural wastes, scientific works are produced with different aims and goals, making comparisons among studies difficult. However, in all studies reported in the literature, specifically in the areas of environmental chemistry or agronomy and focused on organic agriculture, results and conclusions are consistent with those of this study; organic wastes prepared as inputs for organic agriculture can be applied in the planting of sweet pepper or other crops of economic and social interest.

\section{Chromium}

For the dynamics of $\mathrm{Cr}$, the absorption of $\mathrm{Cr}$ (III) begins at the root, followed by transport through the tissues of the stem and stalks, reaching the leaves and fruit (Gropper et al. 2009; Thor et al. 2011; Hua et al. 2012). In this study, in some of these stages, Cr accumulation occurred (Table 8).

Initially, the root is expected to act as a type of filter that prevents assimilation of an excessive concentration of $\mathrm{Cr}$ by the plant, with accumulation in root tissues (Gropper et al. 2009; Thor et al. 2011; Hua et al. 2012). In the rhizosphere, the $\mathrm{Cr}$ (III) levels varied among treatments, although no trend was observed, with values ranging from 23.86 to $65.12 \mu \mathrm{g} \mathrm{kg}^{-1}$. However, for the treatments SP-dYL, SP-NPK, SP-STD, and $\mathrm{SP}-1.5 \%-\mathrm{S}, \mathrm{Cr}(\mathrm{III})$ was below the detectable level in roots, indicating metal absorption followed by transport, without accumulation in the root system.

In general, the $\mathrm{Cr}(\mathrm{III})$ concentrations varied as follows: fruits $>$ stem and stalks $>$ leaves $=$ root, with exceptions (Table 8). The $\mathrm{Cr}$ (III) levels in fruits, stems and stalks were higher than those in the other tissues, most likely because of 
Table 8 Chromium distribution in vegetal tissues and organs (roots, stems, stalks, leaves and fruits) of sweet peppers plants

\begin{tabular}{lllll}
\hline & Roots $\left(\mu \mathrm{g} \mathrm{kg}^{-1}\right)$ & $\begin{array}{l}\text { Stem and stalks } \\
\left(\mu \mathrm{gg}^{-1}\right)\end{array}$ & Leaves $\left(\mu \mathrm{g} \mathrm{kg}^{-1}\right)$ & Fruits $\left(\mu \mathrm{kg}^{-1}\right)$ \\
\hline SP-dYL & $<$ LOQ & $60.71 \mathrm{a}$ & $41.65 \mathrm{a}$ & - \\
SP-NPK & $<$ LOQ & $61.69 \mathrm{a}$ & $41.93 \mathrm{a}$ & $145.06 \mathrm{a}$ \\
SP-1.5\%-STD & $<$ LOQ & $61.77 \mathrm{a}$ & $41.64 \mathrm{a}$ & $145.40 \mathrm{ab}$ \\
SP-3.0\%-STD & $<$ LOQ & $62.81 \mathrm{a}$ & $41.60 \mathrm{a}$ & $156.49 \mathrm{ab}$ \\
SP-6.0\%-STD & $<$ LOQ & $64.50 \mathrm{a}$ & $41.57 \mathrm{a}$ & $159.24 \mathrm{ab}$ \\
SP-1.5\%-S & $<$ LOQ & $61.74 \mathrm{a}$ & $41.85 \mathrm{a}$ & $165.12 \mathrm{bc}$ \\
SP-3.0\%-S & $44.56 \mathrm{~cd}$ & $82.23 \mathrm{~b}$ & $41.74 \mathrm{a}$ & $165.20 \mathrm{bc}$ \\
SP-6.0\%-S & $33.61 \mathrm{bc}$ & $82.29 \mathrm{~b}$ & $41.64 \mathrm{a}$ & $164.83 \mathrm{bc}$ \\
SP-1.5\%-C & $<$ LOQ & $82.19 \mathrm{~b}$ & $41.53 \mathrm{a}$ & $165.22 \mathrm{bc}$ \\
SP-3.0\%-C & $44.18 \mathrm{~cd}$ & $92.44 \mathrm{c}$ & $41.53 \mathrm{a}$ & $165.12 \mathrm{bc}$ \\
SP-6.0\%-C & $24.99 \mathrm{a}$ & $82.28 \mathrm{bc}$ & $41.69 \mathrm{a}$ & $164.90 \mathrm{bc}$ \\
SP-1.5\%-SC & $56.01 \mathrm{bcd}$ & $82.27 \mathrm{~b}$ & $41.58 \mathrm{a}$ & $164.88 \mathrm{bc}$ \\
SP-3.0\%-SC & $23.86 \mathrm{ab}$ & $82.19 \mathrm{~b}$ & $41.60 \mathrm{a}$ & $165.03 \mathrm{bc}$ \\
SP-6.0\%-SC & $65.12 \mathrm{e}$ & $83.20 \mathrm{bc}$ & $41.56 \mathrm{a}$ & $164.69 \mathrm{bc}$ \\
\hline
\end{tabular}

$S P$ sweet pepper, $d Y L$ dystrophic yellow latosol, $S T D$ vermicompost control, $S$ tannery sludge, $C$ tanned chips, $S C$ mixture of tannery sludge and tanned chips

Values in the same column followed by the same letter are not significantly different at $p<0.05$ according to Duncan's test their abilities to accumulate metals in their cells and tissues. In the leaves, the levels of $\mathrm{Cr}$ (III) were not significantly different among the treatments, $\sim 41 \mu \mathrm{g} \mathrm{kg}^{-1}$. In the stems and stalks, the levels of $\mathrm{Cr}(\mathrm{III})$ in the treatments $\mathrm{SP}-\mathrm{dYL}, \mathrm{SP}-\mathrm{NPK}$, $\mathrm{SP}-\mathrm{STD}$, and $\mathrm{SP}-1.5 \%-\mathrm{S}$ were statistically similar, ranging between 60.71 and $64.50 \mu \mathrm{g} \mathrm{kg}^{-1}$; in the other treatments, levels of $\mathrm{Cr}$ (III) were also not significantly different, ranging from 82.19 to $92.44 \mathrm{\mu g} \mathrm{kg}^{-1}$ (ANOVA bootstrap, $p<0.05$; Table 8).

Finally, the fruits are the organs that are of greatest concern because the food security of the consumer is ultimately affected (Gropper et al. 2009; Thor et al. 2011; Hua et al. 2012). In the sweet peppers, $\mathrm{Cr}$ (III) concentration varied between 145.06 and $165.20 \mu \mathrm{g} \mathrm{kg}^{-1}$. Fruits cropped in the treatments $\mathrm{SP}-\mathrm{NPK}$ and $\mathrm{SP}-\mathrm{STD}$, at all concentrations, had levels of $\mathrm{Cr}$ (III) that were statistically similar. The $\mathrm{Cr}$ (III) levels determined in the treatments involving vermicomposted tannery residues were also statistically similar $(\mathrm{SP}-\mathrm{S}, \mathrm{SP}-\mathrm{C}$ and SP-SC; ANOVA bootstrap, $p<0.05$; Table 8). Additionally, tannery residues added in vermicomposting did not increase the $\mathrm{Cr}$ contents in fruit because the fruit concentrations of $\mathrm{Cr}$ (III) were statistically similar to those quantified in the fruits that received the vermicompost control (VRCSTD) at the same concentration $(1.5 \%, 3.0 \%$ or $6.0 \% \mathrm{~V} / \mathrm{V})$.

When comparing the $\mathrm{Cr}$ (III) determined in the fruits in this study with other foods from different studies that are commonly reported as 'Cr-rich' or a 'Cr-source', at the level of chromium enrichment in our cropped red sweet peppers, the fruits would be available for human consumption (Table 9). For example, broccoli has $22.0 \mu \mathrm{g} \mathrm{Cr} 100 \mathrm{~g}^{-1}$, and brown bread and potatoes have 4.4 and $1.5 \mu \mathrm{g} \mathrm{Cr} 100 \mathrm{~g}^{-1}$, respectively. In red and green grapes, the $\mathrm{Cr}$ concentrations are 6.5 and $2.1 \mu \mathrm{g} \mathrm{Cr} 100 \mathrm{~g}^{-1}$, respectively. In our study, red sweet pepper showed, in general, concentrations ranging from 3.8 to $21.4 \mu \mathrm{g} \mathrm{Cr} 100 \mathrm{~g}^{-1}$, which are close to the concentrations present in other foods (Vique et al. 1997; Oliveira and Marchini 2008; NHI 2012).

\section{Conclusions}

The present study confirmed the expectation that the vermicomposted tannery wastes can be applied in the organic cultivation of sweet pepper. The vermicompost addition was biostimulating to the plants, influencing development positively, in addition to increasing fruit production. Although the fruits obtained in the SP-NPK (reference treatment) were statistically similar in characteristics to those cultivated with vermicomposted tannery wastes, the production in this treatment was limited to one fruit per plant, whereas in other treatments, up to three red sweet peppers were harvested per plant. Based on the results obtained in the agronomic assays, the suggested dosage to be applied in the organic cultivation of sweet pepper was the $6.0 \%$ of vermicompost. Also, mixing both forms of residues, sludge and tanned chips, it is possible to reach a best agronomic efficiency of the vermicompost, by increasing significantly the fruit production. When the levels of $\mathrm{Cr}$ were investigated in the plant tissues and organs, only $\mathrm{Cr}$ (III) was detected and quantified, as expected. The highest $\mathrm{Cr}$ content was found in the fruits; however, the $\mathrm{Cr}$ content was the same in fruits in all treatments, which demonstrated that the addition of tannery 
Table $9 \mathrm{Cr}$ (III) concentration in the cropped red sweet pepper and comparison with those in other foods found in the literature

\begin{tabular}{|c|c|c|}
\hline & $\begin{array}{l}\mathrm{Cr}(\mathrm{III})(\mu \mathrm{g} \mathrm{Cr} \\
\left.100 \mathrm{~g}^{-1} *\right)\end{array}$ & Reference \\
\hline \multicolumn{3}{|l|}{ Sweet pepper } \\
\hline $\mathrm{SP}-\mathrm{dYL}$ & $14.0 \mathrm{bcd}$ & \\
\hline $\mathrm{SP}-\mathrm{NPK}$ & $6.7 \mathrm{abc}$ & \\
\hline $\mathrm{SP}-1.5 \%-\mathrm{STD}$ & $14.5 \mathrm{bcd}$ & \\
\hline $\mathrm{SP}-3.0 \%-\mathrm{STD}$ & $21.4 \mathrm{~d}$ & \\
\hline $\mathrm{SP}-6.0 \%-\mathrm{STD}$ & $3.8 \mathrm{a}$ & \\
\hline $\mathrm{SP}-1.5 \%-\mathrm{S}$ & 7.7abc & \\
\hline $\mathrm{SP}-3.0 \%-\mathrm{S}$ & $17.6 \mathrm{~cd}$ & \\
\hline $\mathrm{SP}-6.0 \%-\mathrm{S}$ & $6.1 \mathrm{ab}$ & \\
\hline $\mathrm{SP}-1.5 \%-\mathrm{C}$ & $13.9 \mathrm{bcd}$ & \\
\hline $\mathrm{SP}-3.0 \%-\mathrm{C}$ & $18.6 \mathrm{~d}$ & \\
\hline $\mathrm{SP}-6.0 \%-\mathrm{C}$ & $4.0 \mathrm{a}$ & \\
\hline $\mathrm{SP}-1.5 \%-\mathrm{SC}$ & $14.3 \mathrm{bcd}$ & \\
\hline $\mathrm{SP}-3.0 \%-\mathrm{SC}$ & $16.6 \mathrm{~cd}$ & \\
\hline $\mathrm{SP}-6.0 \%-\mathrm{SC}$ & $14.0 \mathrm{bcd}$ & \\
\hline Broccoli & 22.0 & Oliveira and Marchini (2008) \\
\hline Potatoes & 1.5 & NHI (2012) \\
\hline Brown bread & 4.4 & NHI (2012) \\
\hline Green grapes & 2.1 & Vique et al. (1997) \\
\hline Red grapes & 6.5 & Vique et al. (1997) \\
\hline Apple & 0.8 & NHI (2012) \\
\hline Orange juice & 1.0 & NHI (2012) \\
\hline Garlic & 60.0 & NHI (2012) \\
\hline
\end{tabular}

$S P$ sweet pepper, $d Y L$ dystrophic yellow latosol, $S T D$ vermicompost control, $S$ tannery sludge, $C$ tanned chips, $S C$ mixture of tannery sludge and tanned chips

Values in the same column (only for the sweet peppers) followed by the same letter are not significantly different at $p<0.05$ according to Duncan's test

* $\mu \mathrm{g}$ of $\mathrm{Cr}$ per $100 \mathrm{~g}$ of food

residues in the vermicompost did not negatively influence the quality, health or food security of the produced sweet peppers.

Acknowledgements The authors thank FAPESP - Fundação de Amparo à Pesquisa do Estado de São Paulo (State of São Paulo, Brazil) for providing grants to R. R. Nunes (Process 2013/00744-0) and CNPq - Conselho Nacional de Desenvolvimento Científico e Tecnológico (Brazil) for the support (Process 306715/2013-9).

Open Access This article is distributed under the terms of the Creative Commons Attribution 4.0 International License (http://creativeco mmons.org/licenses/by/4.0/), which permits unrestricted use, distribution, and reproduction in any medium, provided you give appropriate credit to the original author(s) and the source, provide a link to the Creative Commons license, and indicate if changes were made.

\section{References}

Abul-Soud MA, Emam MSA, Abdrabbo MAA et al (2014) Sustainable urban horticulture of sweet pepper via vermicomposting in summer. J Adv Agric 3:110-122. https://doi.org/10.13140/ RG.2.1.1491.9201

Aguilera-Gomez L, Davies FT Jr, Olalde-Portugal V et al (1999) Influence of phosphorus and endomycorrhiza (Glomus intraradices) on gas exchange and plant growth of chile ancho pepper (Capsicum annuит L. cv. San Luis). Photosynthetica 36:441-449. https://doi. org/10.1023/A:1007032320951

Aira M, Sampedro L, Monroy F, Domínguez J (2008) Detritivorous earthworms directly modify the structure, thus altering the functioning of a microdecomposer food web. Soil Biol Biochem 40:2511-2516. https://doi.org/10.1016/j.soilbio.2008.06.010

Albuquerque FS, Silva EFF, Albuquerque Filho JAC, Nunes MFFN (2011) Growth and yield of sweet pepper fertigated under different irrigation depths and potassium doses. Rev Bras Eng Agrícola e Ambient 15:686-694. https://doi.org/10.1590/S1415-4366201100 0700006

Arancon NQ, Edwards CA, Lee S, Byrne R (2006) Effects of humic acids from vermicomposts on plant growth. Eur J Soil Biol 42:S65-S69. https://doi.org/10.1016/j.ejsobi.2006.06.004

Bachman GR, Metzger JD (2008) Growth of bedding plants in commercial potting substrate amended with vermicompost. Bioresour Technol 99:3155-3161. https://doi.org/10.1016/j.biort ech.2007.05.069

Belay AA (2010) Impacts of chromium from tannery effluent and evaluation of alternative treatment options. J Environ Prot 01:53-58. https://doi.org/10.4236/jep.2010.11007

Canellas LP, Santos GA (2005) Humosfera. CCTA/UENF, Campos dos Goytacazes

CETESB (2005) Curtumes. Companhia Ambiental do Estado de São Paulo, São Paulo

Dixit S, Yadav A, Dwivedi PD, Das M (2015) Toxic hazards of leather industry and technologies to combat threat: a review. J Clean Prod 87:39-49. https://doi.org/10.1016/j.jclepro.2014.10.017

EMBRAPA (2017) Manual de métodos de análise de solo. EMBRAPA Solos, Rio de Janeiro

EMBRAPA (2018) Sistema brasileiro de classificação de solos. EMBRAPA Solos, Rio de Janeiro

Epstein E (1997) The science of composting. Technomic Publishing Company, Lancaster

Epstein E, Bloom AJ (2006) Nutrição mineral de plantas: princípios e perspectivas. Editora Planta, Londrina

Faquin V (2005) Nutrição mineral de plantas. Editora UFLA, Lavras

Fontes PCR (2006) Diagnóstico do estado nutricional das plantas. UFV, Viçosa

Gopinath KA, Saha S, Mina BL et al (2009) Bell pepper yield and soil properties during conversion from conventional to organic production in Indian Himalayas. Sci Hortic (Amst) 122:339-345. https ://doi.org/10.1016/j.scienta.2009.05.016

Gropper SS, Smith JL, Groff J (2009) Advanced nutrition and human metabolism. Cengage Learning, Boston

Herman MAB, Nault BA, Smart CD (2008) Effects of plant growthpromoting rhizobacteria on bell pepper production and green peach aphid infestations in New York. Crop Prot 27:996-1002. https://doi.org/10.1016/j.cropro.2007.12.004

Hua Y, Clark S, Ren J, Sreejayan N (2012) Molecular mechanisms of chromium in alleviating insulin resistance. J Nutr Biochem 23:313-319. https://doi.org/10.1016/j.jnutbio.2011.11.001

Huges HBN (1980) The biology of polluted waters. University Press, Liverpool

ISO 10390 (1994) Soil quality: determination of pH. International Organization for Standardization, Genebra 
ISO 10694 (1995) Soil quality: determination of organic and total carbon after dry combustion (elementary analysis). International Organization for Standardization, Genebra

ISO 11260 (1994) Soil quality: determination of effective cation exchange capacity and base saturation level using barium chloride solution. International Organization for Standardization, Genebra

Karimi H, Mokhtari M, Salehi F et al (2017) Changes in microbial pathogen dynamics during vermicomposting mixture of cow manure-organic solid waste and cow manure-sewage sludge. Int J Recycl Org Waste Agric 6:57-61. https://doi.org/10.1007/s4009 3-016-0152-4

Kaur A, Singh J, Vig AP et al (2010) Cocomposting with and without Eisenia fetida for conversion of toxic paper mill sludge to a soil conditioner. Bioresour Technol 101:8192-8198. https://doi. org/10.1016/j.biortech.2010.05.041

Kenyangi A, Blok W (2013) Vermicompost as a component in potting mixes for growth promotion in ornamental plants. Rwanda J 28:53-63. https://doi.org/10.4314/rj.v28i0.4

Llaven MAO, Jimenez JLG, Coro BIC et al (2008) Fruit characteristics of bell pepper cultivated in sheep manure vermicompost substituted soil. J Plant Nutr 31:1585-1598. https://doi. org/10.1080/01904160802244738

Lorenzeni MZ, Rezende R, Souza AHCS et al (2015) Estimativa da área foliar em função das dimensões lineares da folha de pimentão. In: XLIV Congresso Brasileiro de Engenharia Agrícola, São Pedro

Makkar C, Singh J, Parkash C (2017) Vermicompost and vermiwash as supplement to improve seedling, plant growth and yield in Linum usitassimum L. for organic agriculture. Int J Recycl Org Waste Agric 6:203-218. https://doi.org/10.1007/s40093-017-0168-4

Malavolta E (1980) Elementos de nutrição mineral de plantas. Ceres, São Paulo

Malavolta E, Vitti GC, Oliveira SA (1997) Avaliação do estado nutricional das plantas: princípios e aplicações. POTAFOS, Piracicaba

Marti HR, Mills HA (1991) Calcium uptake and concentration in bell pepper plants as influenced by nitrogen form and stages of development. J Plant Nutr 14:1177-1185. https://doi. org/10.1080/01904169109364276

Ndegwa PM, Thompson SA, Das KC (2000) Effects of stocking density and feeding rate on vermicomposting of biosolids. Bioresour Technol 71:5-12. https://doi.org/10.1016/S0960-8524(99)00055-3

NEN 5754 (1994) Determination of organic matter content in soil as loss-on-ignition. Netherlands Normalisation Institute, Delft

NHI (2012) Office of dietary supplements. Dietary supplement fact sheet: chromium. In: National Institutes of Health. http://ods. od.nih.gov. Accessed 30 Nov 2017

Nunes RR, Bontempi RM, Mendonça G et al (2016) Vermicomposting as an advanced biological treatment for industrial waste from the leather industry (tanneries). J Environ Sci Health Part B 51:271277. https://doi.org/10.1080/03601234.2015.1128737

Oliveira JED, Marchini JS (2008) Ciências nutricionais. Sarvier, São Paulo

Pereira AL (1990) Cultura do pimentão. DNOCS, Fortaleza

Ramesh P, Singh M, Panwar NR et al (2006) Response of pigeonpea (Cajanus cajan) varieties to organic manures and their influence on fertility and enzyme activity of soil. Indian J Agric Sci $76: 252-254$

Ravindran B, Dinesh SL, Kennedy LJ, Sekaran G (2008) Vermicomposting of solid waste generated from leather industries using epigeic earthworm Eisenia foetida. Appl Biochem Biotechnol 151:480-488. https://doi.org/10.1007/s12010-008-8222-3
Ribeiro LG, Lopes JC, Martins Filho S, Ramalho SS (2000) Adubação orgânica na produção de pimentão. Hortic Bras 18:134-137. https ://doi.org/10.1590/S0102-05362000000200012

Ricci MSF (1996) Manual de vermicompostagem. EMBRAPA Rondônia, Porto Velho

Riga P, Anza M (2003) Effect of magnesium deficiency on pepper growth parameters: implications for determination of magnesium critical value. J Plant Nutr 26:1581-1593. https://doi.org/10.1081/ PLN-120022367

Scaglia B, Nunes RR, Rezende MOO et al (2016) Investigating organic molecules responsible of auxin-like activity of humic acid fraction extracted from vermicompost. Sci Total Environ 562:289-295. https://doi.org/10.1016/j.scitotenv.2016.03.212

Scivittaro WB, Melo AMTA, Tavares M et al (1999) Caracterização de híbridos de pimentão em cultivo protegido. Hortic Bras 17:147150. https://doi.org/10.1590/S0102-05361999000200014

Silva MAG, Boaretto AE, Muraoka T et al (2001) Efeito do nitrogênio e potássio na nutrição do pimentão cultivado em ambiente protegido. Rev Bras Ciência do Solo 25:913-922. https://doi. org/10.1590/S0100-06832001000400014

Silva MAA, Escobedo JF, Galvani E (2002) Influência da cultura do pimentão (Capsicum annuum L.) nos elementos ambientais em ambiente protegido. Irriga 7:230-240. https://doi.org/10.15809/ irriga.2002v7n3p230

Singh RP, Singh P, Araujo ASF et al (2011) Management of urban solid waste: vermicomposting a sustainable option. Resour Conserv Recycl 55:719-729. https://doi.org/10.1016/j.resco nrec.2011.02.005

Swift RS (1996) Organic matter characterization. In: Sparks DL, Page AL, Helmke PA et al (eds) Methods of soil analysis: chemical methods. Soil Science Society of America, Madison, pp 1018-1020

Thor MY, Harnack L, King D et al (2011) Evaluation of the comprehensiveness and reliability of the chromium composition of foods in the literature. J Food Compost Anal 24:1147-1152. https://doi. org/10.1016/j.jfca.2011.04.006

Tobiašová E (2011) The effect of organic matter on the structure of soils of different land uses. Soil Tillage Res 114:183-192. https ://doi.org/10.1016/j.still.2011.05.003

Vig AP, Singh J, Wani SH, Dhaliwal SS (2011) Vermicomposting of tannery sludge mixed with cattle dung into valuable manure using earthworm Eisenia fetida (Savigny). Bioresour Technol 102:7941-7945. https://doi.org/10.1016/j.biortech.2011.05.056

Vique CC, Teissedre PL, Cabanis MT, Cabanis JC (1997) Determination and levels of chromium in French wine and grapes by graphite furnace atomic absorption spectrometry. J Agric Food Chem 45:1808-1811. https://doi.org/10.1021/jf960691b

Yang J, Lv B, Zhang J, Xing M (2014) Insight into the roles of earthworm in vermicomposting of sewage sludge by determining the water-extracts through chemical and spectroscopic methods. Bioresour Technol 154:94-100. https://doi.org/10.1016/j.biort ech.2013.12.023

Publisher's Note Springer Nature remains neutral with regard to jurisdictional claims in published maps and institutional affiliations. 